\title{
100 YEARS OF ORDOVICIAN GEOLOGY
}

by

Michael G. Bassett

\begin{abstract}
It is exactly 100 years since the Ordovician System was first proposed by Charles Lapworth. Born from controversy, it is the last of the geological systems to have become universally accepted. In his proposal Lapworth saw the Ordovician in an international context, and the ensuing century of widespread research has justified his views. This article traces some major steps in the international recognition of the System since 1879 .
\end{abstract}

Although Charles Lapworth's original definition of the Ordovician System in 1879 was based essentially on the sequence of strata in Britain, his concept grew from a recognition of the widespread geographical distribution in the Northern Hemisphere of three stratigraphically successive Lower Palaeozoic faunas. In essence, these corresponded to the three faunas first proposed in Bohemia over the preceding 30 years by Joachim Barrande; Lapworth was able to point to the equal validity and correlative value of such a tripartite subdivision in the sequences in Sweden, Bohemia, Britain, and Nor th America:

...To those who interest themselves in the attempted correlation of the Lower Palaeozoic Rocks of the Northern Hemisphere, and who are continually hampered by the want of some clear and unmistakable generic terms expressive of the general parallelism among these widely-separated deposits, the ease and comfort of a classification which imitates Nature herself in placing the three grand members of the Lower Palaeozoic Rocks upon an equal footing, is an advantage of which they are certain in time to avail themselves to the full... (Lapworth, 1879, p. 15.)

The proposed solution of the long-standing Sedgwick-Murchison Cambro-Silurian dispute was therefore more than simply one of nomenclature, but reflected Lapworth's conviction that the separation of a central Lower Palaeozoic system would 'enable us to lay down a palaeontological line of demarcation far more strictly synchronous throughout its geographical range' than had previously been possible (Lapworth, 1879, p. 11); that is, he saw it as a means of effecting closer international correlations.

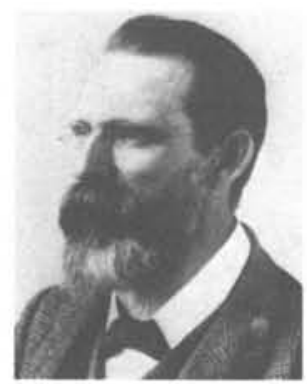

Figure 1. Charles, Lapworth (1842-1920), author of the Ordovician System. (From Proceedings of the Geologists' Association, vol. 50, pl. 19).

There was remarkably little initial reaction to Lapworth's proposal, which in the succeeding few years appears to have had little effect in geological publications. Lapworth's paper had appeared in the January issue of the Geological Magazine for 1879 , and in that year the only reference to it was in the March issue of the same journal, when the Shropshire geologist Charles Callaway wrote in support of a 'tripartite division of the Silurian and Cambrian formations', and of an Ordovician System 'as a proper name for the rocks of the second fauna'. Other than this, however, British geologists made virtually no mention of the new System and continued to refer to strata of 'Cambro-Silurian' or 'Lower Silurian' age. Many papers through the 1880 's simply ducked the issue altogether, and the basic stratigraphy of a good number of Lower Palaeozoic areas in Britain was described without any comment on the age of the rocks in question!

The first real support came from abroad. The influential Quarterly Journal of the Geological Society of London had not mentioned the word Ordovician until 1882 when Friedrich Schmidt, the well-known Russian geologist and a Foreign Member of the Society, communicated a paper on the Palaeozoic of the Baltic Provinces, and in it for the first time indicated the equivalence of the 'Lower Silurian' and the Ordovician (Schmidt, 1882, p. 517). Remarkably, in the succeeding paper in the Quarterly Journal, Lapworth (1882) was to publish his classic account of the Girvan district in Scotland, which makes no mention of the term Ordovician. In the same year, however, the eminent American geologist $\mathrm{T}$. Sterry Hunt was the first in North America to advocate adoption of the new System when he presented a paper to the Royal Society of Canada (Hunt, 1883). Gradually, others were to follow suit.

The reluctance of British geologists to accept Lapworth's new classification was influenced largely by the determined defence of Sedgwick's Cambrian System by the Cambridge school, led by T. McKenny Hughes who had succeeded Sedgwick to the Woodwardian Professorship. In his biography of Sedgwick, Hughes was later to summarize his views on the matter (Clark and Hughes, 1890, p. 555): 'A proposal has been made to take all Sedgwick's Arenig and Bala Beds, and Murchison's Llandeilo and Caradoc, and constitute, not Upper Cambrian, not Lower Silurian, but Ordovician, with a view to putting an end to controversy! One shell is given to Sedgwick, the other to Murchison, but who gets the oyster?' ( $A$ later retort to this query suggested that the oyster went to Lapworth because he deserved it as the one who had discovered the pearl inside!)

Hughes' viewpoint was supported at first by his pupil (and eventual successor to the Cambridge chair) John E. Marr, who in 1881 specifically rejected the use of the term Ordovician. Significantly however, Marr also mentioned the need to bring the problem of nomenclature before the International Commission for the Unification of Geological Nomenclature (a body of the International Geological Congress). Full international discussion of the issue was thus in sight.

At the third session of the IGC in Berlin (1885), Marr again rejected Lapworth's classification, though he noted that his recommendation for the adoption of Sedgwick's Cambrian did not meet with the approval of many members of the subcom- 
mittee set up to investigate the matter; no decisions were taken at that time. At the following Congress held in London in 1888, the debate continued on the question of classification and nomenclature of the 'Cambro-Silurian' rocks. Lapworth himself made a plea for the Congress 'to unite in suggesting the expediency of that term (i.e. Ordovician) which the unbiassed geologists of the future will of themselves be naturally led to adopt by the progress of geology and necessities of the case'.

In this he was now supported publicly for the first time by Marr, who observed that 'systems must now be separated on palaeontological grounds, each system containing a distinct fauna, and that this was the case with the three systems of the Lower Palaeozoic rocks'. Marr also pointed out that 'apart from all other considerations, the term Ordovician had the advantage that when used by an author, the meaning of the terms Cambrian and Silurian as used by him was thereby also defined'. Opposing points of view were put forward, but the Congress again came to no formal decision on the matter. Nevertheless, it was one of the turning points in the debate: from then on the use of the term Ordovician became more widely accepted.

It is not clear exactly when Marr changed his views between 1885 and 1888 , but his growing stature as a geologist was such that his opinions carried considerable weight. His statement at the 1888 Congress made it clear that he had come to recognize the validity of the three Lower Palaeozoic faunas, and in this he was undoubtedly influenced directly by Lapworth. Despite the continued opposition of McKenny Hughes, the Cambridge school as a whole now gradually followed Marr's rationale. He and many others increasingly relied on the graptolite correlations first demonstrated by Lapworth so convincingly in the Southern Uplands of Scotland and in Wales, and on the zonal scheme established in areas such as Dob's Linn near Moffat (Fig. 2). The growing application of graptolites in stratigraphy in many parts of the world became one of the most powerful arguments in support of Lapworth's classification, allowing the recognititon of rocks equivalent to the type Ordovician of Britain.

The taxonomic basis for this graptolite stratigraphy, initially due largely to Lapworth himself, became firmly established in the early years of the 20th century when Miss G.L. Elles and Miss E.M.R. Wood published their comprehensive monograph on British graptolite faunas (1901-18). The work was carried out under Lapworth's direction, and became the touchstone on which virtually all Lower Palaeozoic correlations were based.

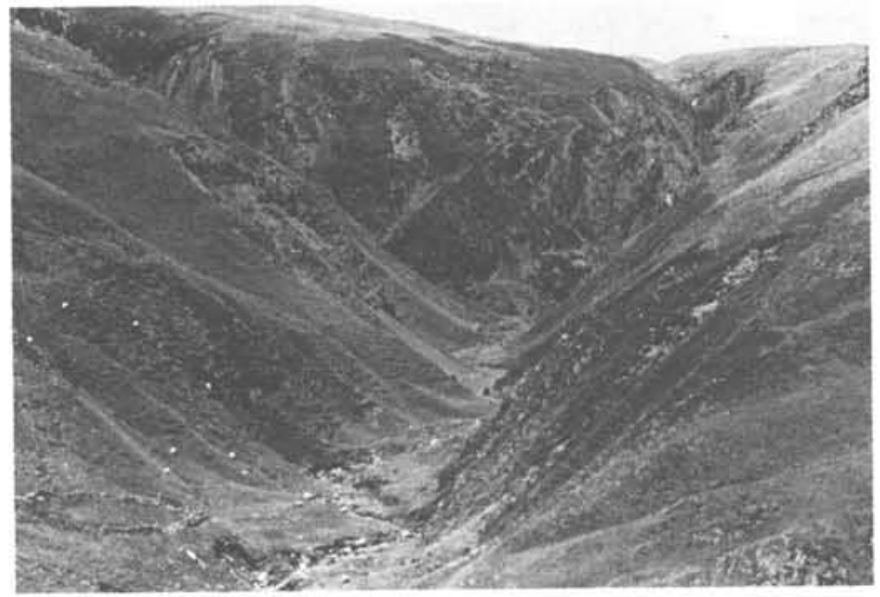

Figure 2. Lapworth's classic section at Dob's Linn, near Moffat, Southern Uplands of Scotland. Exposure shows upper Ordovician Hartfell Shales overlain conformably by lower Silurian Birkhill Shales; rich graptolite faunas are present throughout the section. Lapworth's Main Cliff is to the left, Linn Branch to the far left, and Long Burn in the distance to the right. (Photo courtesy J.K. Ingham).
The opening of the 20th century also saw the first 'official' recognition of the Ordovician System. At the 1888 Congress in London, Archibald Geikie, Director of the Geological Survey in Britain and a staunch supporter of Murchison and the Silurian System, had spoken against Lapworth's classification, and it was not adopted by the British Survey. In 1900 , however, Geikie retired and was succeeded by J.J. Teall, who in his first Summary of Progress (for 1901, published in 1902) used the term Ordovician without comment, and the Annual Report of the Survey for the same year referred to Ordovician fossils, again without comment. By 1906 the Ordovician replaced 'Lower Silurian' on the Survey maps, and was used consistently from then on.

In 1903, the Ordovician System was adopted officially by the United States Geological Survey, and although many other Surveys continued to use 'Lower Silurian' for some time, the latter term gradually fell into disuse in official maps and memoirs throughout the world. A brief but notable departure from this came when J.M. Clarke and Charles Schuchert (U.S.A.) advocated in 1903 the use of 'Champlainian', which had first been used by James Hall as early as 1842 for approximately the same stratigraphical period. This term was then adopted for some years by the Geological Survey of New York, and used by Schuchert himself until 1924, but even though 'Champlainian' has priority over 'Ordovician', its re-introduction gained little support and it too fell into disuse.

Of course, throughout this period of continuing debate on nomenclature and classification, rocks now classified as Ordovician were being mapped in many parts of the world, and Ordovician fossils were described and illustrated in numerous systematic studies; the tools for correlation became more and more refined. The 20th century has seen a continuation of this work, and there has been increasing emphasis placed on attempts to correlate and standardize the various local subdivisions of the Ordovician System that have been erected in different countries. Rocks of Ordovician age have now been recognized in every continent except Antarctica, ranging from Australasia to the Arctic (Figs. 3 and 4).

Thus acceptance of the term Ordovician took place mainly through common usage rather than official decree, and it was not until 1960 that it was granted formal international approval. Prior to the twenty-first session of the International Geological Congress at Copenhagen in 1960, a Committee on the Terminology of the Silurian and Ordovician had been convened under the chairmanship of Prof. L. Störmer (Norway). This Committee presented the following proposals

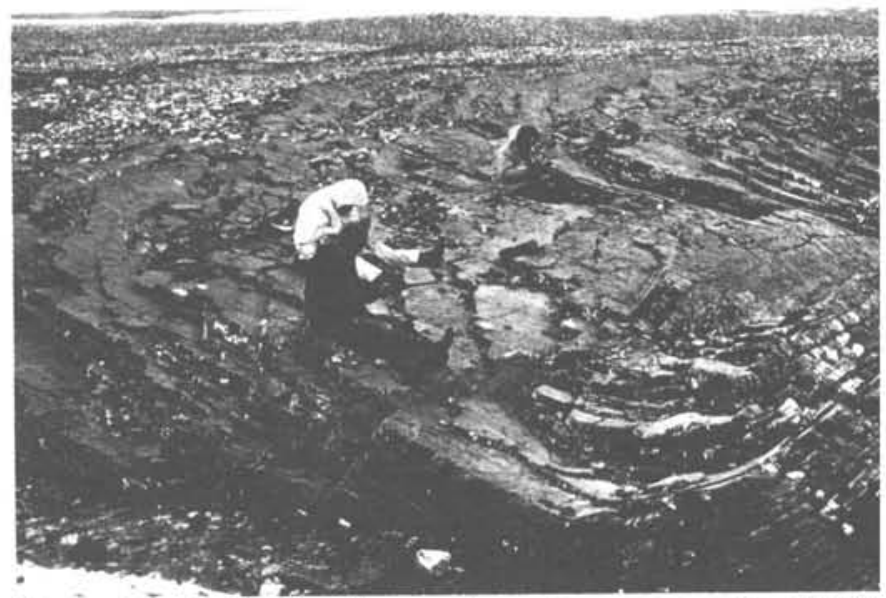

Figure 3. Collecting faunas from the upper part of the Valhallfonna Formation (mid Ordovician) in North Ny Friesland, Spitsbergen. Paleontologisk Museum (Oslo)/Norsk Polarinstitutt Expedition, 1972. (Photo courtesy R.A. Fortey). 


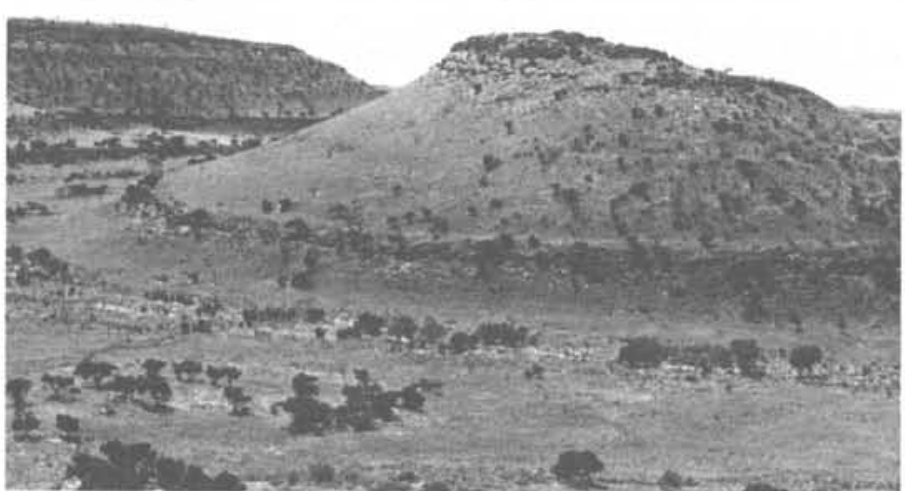

Figure 4. Ordovician outcrops in central Queensland, Australia; the beds belong to the early Ordovician Nora Formation and Carlo Sandstone. The faunas of this area have never been described. (Photo courtesy R.A. Fortey).

to the Commission on Stratigraphy:

1. Two systems are to be recognized between the Cambrian and Devonian Systems

2. The name of the lower system shall be Ordovician

3. The name of the upper system shall be Silurian.

The proposals were approved by the Commission on Stratigraphy on August 22nd, 1960, and adopted by the Congress at its Council meeting on the following day. The existence of the Ordovician System was finally confirmed 80 years after its birth.

The development of international cooperation in Ordovician studies, stimulated partly through the International Geological Congress, has been particularly notable during the past 20 years. At the twenty-fourth session in Montreal in 1972, the Commission on Stratigraphy of the International Union of Geological Sciences proposed that the time was ripe for the establishment of a Subcommission on Ordovician Stratigraphy, and Prof. Alwyn Williams (U.K.) was invited to organize such a group and become the founding Chairman.

Fittingly, the Subcommission's first meeting was convened at the University of Birmingham, England in September of 1974 on the occasion of The Palaeontological Association's inter- national symposium on the Ordovician System. This was the University at which Lapworth had held the chair between 1881 and 1913, and at which the new Subcommission Chairman was now the Lapworth Professor. At the same meeting, Boundary Working Groups were established to investigate the various problems and possibilities of formally defining the lower and upper limits of the Ordovician; active studies by these various groups are now being carried out throughout the world.

The Birmingham symposium was the second international gathering at which Ordovician specialists from many countries met to discuss various aspects of the System. The first had been at Brest in France in September, 1971 (in conjunction with Silurian specialists), and in 1977 a third meeting took place at Columbus, Ohio, U.S.A. On each of these occasions, field excursions formed an integral part of the programme (Fig. 5), allowing Ordovician workers from different regions to study a host of topics at first hand. Another symposium is now planned for 1982 in Oslo, Norway.

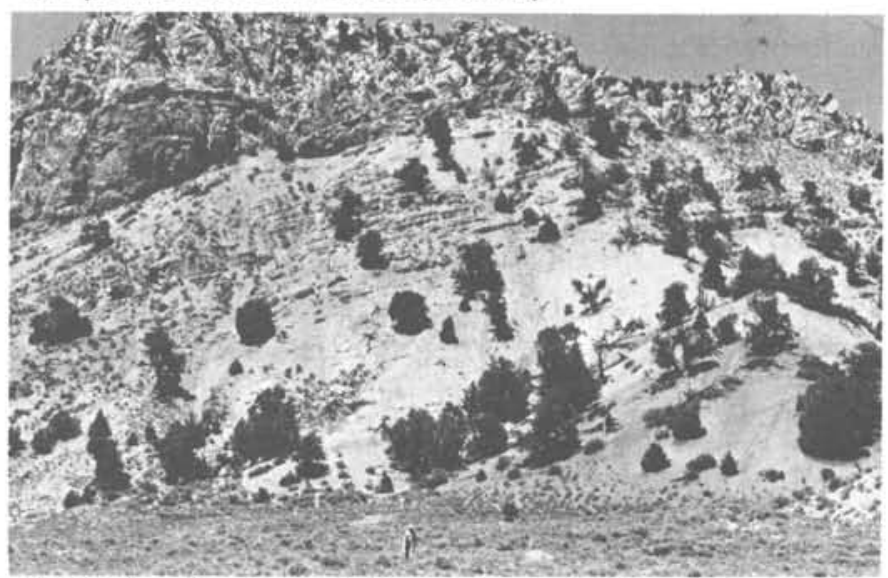

Figure 5. The type Whiterock (early Middle Ordovician), N side of Whiterock Canyon, $W$ side of Antelope Valley, Nevada, U.S.A. The section exposes the Ordovician Ninemile and Antelope Valley Limestone formations, faulted over Devonian shales at lower right.

All these meetings have led to an increased understanding of the System and have allowed more meaningful interpretations to be made of world-wide aspects of Ordovician geology, such as correlation, biogeography, and faunal provinces (Fig. 6).

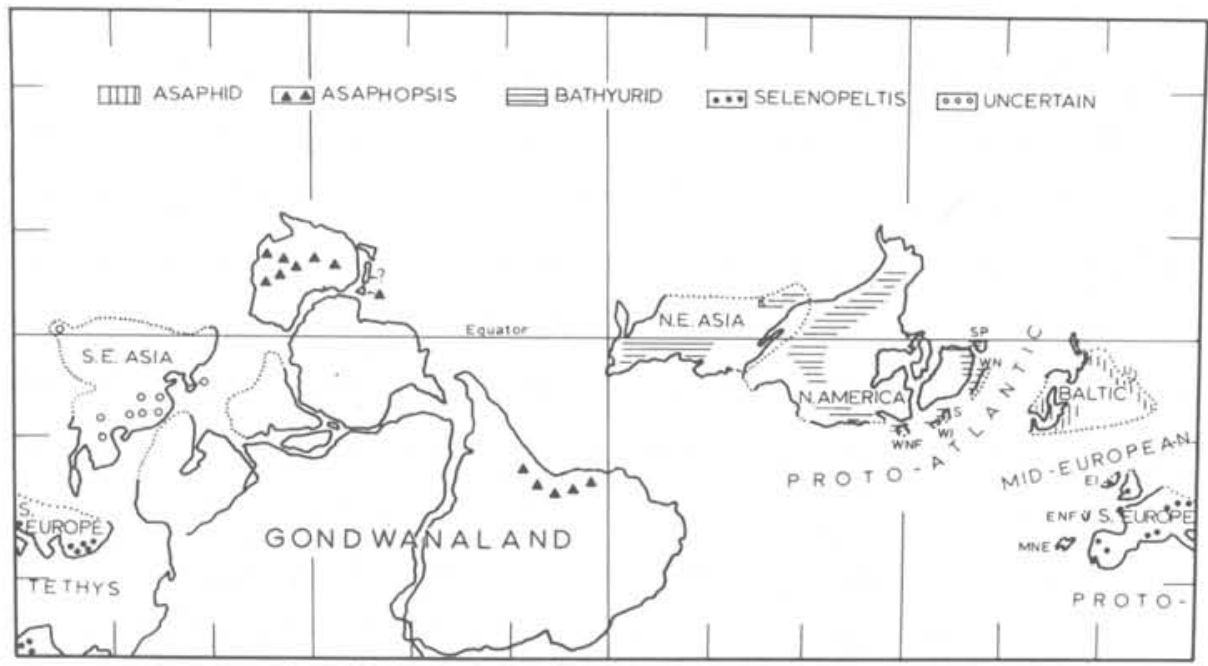

Figure 6. Reconstruction of early-mid Ordovician (Arenig-Llanvirn) palaeogeography and trilobite faunal provinces. $\quad K=$ Kazakhstan; $S=$ Spitsbergen; $W N=$ western Norway; $S=$ Scotland; $W I=$ western Ireland; $W N F=$ western Newfoundland; $U=$ Ural mountains; $E I=$ eastern Ireland; $E N F=$ eastern Newfoundland; $M N E=$ parts of Maritime provinces of eastern North America. (From Whittington and Hughes, 1973, Special Papers in Palaeontology, No. 12, p. 239, text-fig. 2). 
With the firm establishment of the Ordovician Subcommission (now under the Chairmanship of R.J. Ross, Jr., U.S.A.) international links have been forged even more strongly. For example, in May 1977 some Subcommission members were invited by the Soviet Academy of Sciences to visit Moscow and Alma Ata (Kazakhstan) to discuss concepts and problems of stratigraphy and correlation with Soviet colleagues (Fig. 7), and this has led in particular to a better understanding of different terminologies caused by differences in language. And in October 1978, five members of the Subcommission visited the People's Republic of China as guests of the Chinese Academy of Geological Sciences (see EPISODES, Vol. 1979 . No. 1, p. 25); they were able to study many aspects of the Chinese Ordovician both in the field (Fig. 8) and in laboratories. Understanding of this vast region and of its relationships with other Ordovician areas will certainly improve as a result of such cooperative, two-way exchange of information.

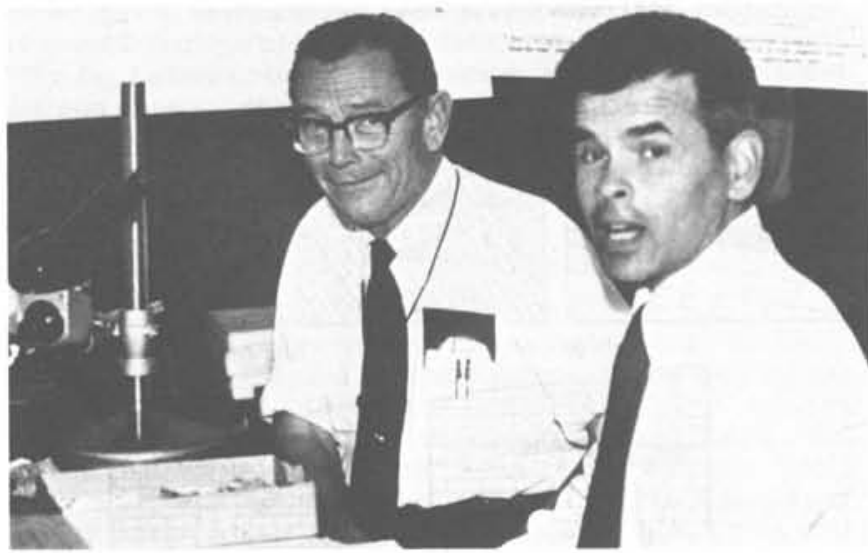

Figure 7. R.J. Ross, Jr. (U.S. Geological Survey), Chairman of the Ordovician Subcommission, and M.K. Apollonov (Kazakhstan Academy of Sciences) discuss Ordovician correlation and trilobite faunas, Alma Ata, Kazakhstan, U.S.S.R., May 1977.

One of the Ordovician Subcommission's current major tasks is to compile correlation charts for each of the continents and parts of continents that may have been palaeotectonic plates or parts of plates during Ordovician time. This is a considerable undertaking, but when completed will form the basis and springboard for other fundamental projects on a world-wide scale; it is part of an effort to gain a better understanding of earth history and events over 400 million years ago. Such a project reflects the enormous progress made in Ordovician geology since 1879 and emphasizes the great amount of data accumulated in those 100 years. Charles Lapworth would surely have approved of both the aims and the spirit of international cooperation embodied in this work.

\section{References}

Callaway, C., 1879, The tripartite division of the Silurian and Cambrian formations: Geological Magazine, Decade 2, (New Series), v.6, p. 142, 143.

Clark, J.W. and Hughes, T. McK., 1890, The life and letters of the Reverend Adam Sedgwick: v. 1, xiv + 539 p.; v.2, viii + 640 p., University Press, Cambridge.

Elles, G.L. and Wood, E.M.R., 1901-1918, A monograph of British graptolites: Palaeontographical Society Monograph, Parts 1-11, a-m, i-clxxii, p. 1-539, pls. 1-52.

Hunt, T.S., 1883, A historical account of the Taconic question in geology, with a discussion of the relations of the Taconian Series to the older crystalline and to the Cambrian rocks - Part 1: Transactions of the Royal Society of Canada, v. 1, sect. 4, p. 217-271.
Lapworth, C., 1879, On the tripartite classification of the Lower Palaeozoic rocks: Geological Magazine, Decade 2, (New Series), v. 6, p. 1-15.

Lapworth, C., 1882, The Girvan succession. Part 1. Stratigraphy: Quarterly Journal of the Geological Society of London, v. 38, p. 537-666, pls. 24, 25.

Marr, J.E., 1881, The classification of the Cambrian and Silurian rocks: Geological Magazine, Decade 2, (New Series), v. 8, p. 245-250.

Schmidt, F., 1882, On the Silurian (and Cambrian) strata of the Baltic provinces of Russia, as compared with those of Scandinavia and the British Isles: Quarterly Journal of the Geological Society of London, v. 38, p. 514-536, pl. 23.

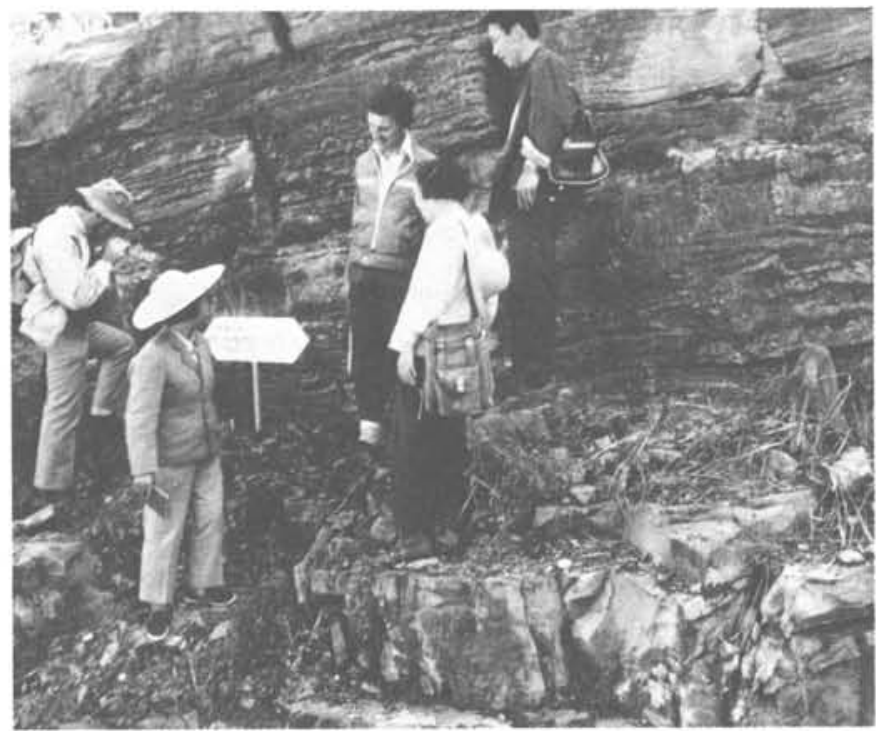

Figure 8. Basal Ordovician Nantsinkuan Formation overlying the Cambrian Sanyutung Formation, near Huanghuachang, $20 \mathrm{~km} \mathrm{~N}$ of Yichang, Peoples Republic of China. Members of the Ordovician Subcommission discussing the section with Chinese colleagues, October 1978: (left to right) B.D. Webby (Australia), Mrs. Tsai Wen-yen (China), J.K. Ingham (U.K.), Chou Tien-mei and Wang Xiao-feng (China). (Photo courtesy R.J. Ross, Jr.

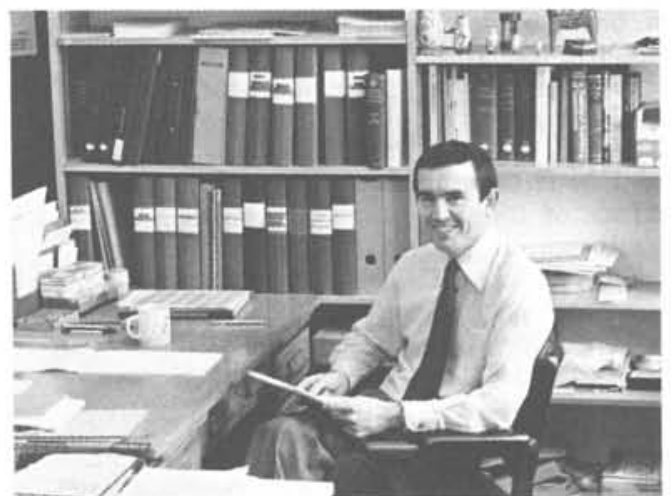

ABOUT THE AUTHOR: Head of the Department of Geology, National Museum of Wales (U.K.), Dr. Michael G. Bassett is both Secretary-General of the IUGS Commission on Stratigraphy and Chairman of IUGS Advisory Board for Publication. His research work has concentrated mainly on Lower Palaeozoic palaeontology and biostratigraphy, particularly brachiopods, in Wales and the Welsh Borderland, but has extended recently to Ordovician and Silurian of Sweden and Norway. An editor of Palaeontology, Dr. Bassett is also associate editor of Lethaia. 